\title{
5. DIDACTIC STRATEGIES FOR THE DEVELOPMENT OF PROFESSIONAL MUSICAL HEARING
}

\section{Luminiţa Duţică 56}

\begin{abstract}
This study suggests an incursion into the issue of the development of professional musical hearing, which is divided into three major sections. Starting from the general to the particular, this approach starts with defining the field of reference - musical hearing, seen as a prerequisite in the training of future artists. Closely related to the curricula and textbooks from the pre-university vocational education, the subject Music Theory - Solfeggio Dictation holds the conceptual and pragmatic frame on the basis of which we offered different solutions for the development of musical hearing. In this respect, I focused my research on the following typologies: melodic, polyphonic, harmonic, dynamic, timbral, with particular reference to the formation of internal hearing and sense of rhythm.
\end{abstract}

Key words: musical hearing, native predispositions, syllabus, Music Theory, didactic strategies

\section{MUSICAL HEARING - ESSENTIAL CONDITION FOR THE TRAINING OF FUTURE ARTISTS}

Musical hearing is a set of skills or native predispositions necessary for the training of future musicians, traits that should be identified and developed since the first years of the pre-school period (3 years old). If we talk about specialized types of education, these skills, native qualities, are tested through a detailed examination, organized before the first year of primary school. The oral tests which condition the success of a child at the admission exam in the first class at a musical high school include: detection of the melodic musical hearing or, respectively, harmonic, of the sense of rhythm and musical memory. Without these early native data that will develop over the years, children will not be able to study and especially to perform in the musical field.

As Ion Gagim states, this area was always fascinating. Thus, "research on the issue of musical skills has started even since the nineteenth century through the works of C. Stumpf (1883, 1890), T. Billroth (1895), A. Faist (1897), M. Meyer (1898) etc. /.../. According to Revesz, musicality itself includes, among other qualities, the faculty of aesthetic enjoyment through music, the ability to get into its disposition, to capture the form and construction of the phrase, the subtle sense of style. K. Seashore, on the contrary, interpreted musicality as a sum of separate talents, unconnected, classifying them into five major groups: auditory sensation and perception, musical action (the musical act itself), musical memory and musical imagination, musical intellect, musical sensitivity. (...)"57.

In the stages of school learning, the mental development of the child is the main reference in the process of acquiring knowledge, of skills and abilities

\footnotetext{
${ }^{56}$ Associate Professor PhD, „George Enescu” University of Arts from Iaşi of Romania, luminitadutica@yahoo.com

${ }^{57}$ Ion Gagim -Dimensiunea psihologică a muzicii/ Psychological Dimension of Music, Iaşi, Ed. Timpul, 2003, p.141
} 
formation, ,the continuous restructuring and training process of certain characteristics, processes, functions and psycho-behavioural structures through the subjective capitalization of the socio - historical experience, in order to amplify the body's adaptive possibilities"58. If we take into account the main stages of mental development of the child, as they are broadly discussed in the volumes concerning age-related psychology by Jean Piaget, Ursula Schiopu etc., we can follow and establish a number of ways of training and development of musical skills and abilities for each age.

Although the contact of the child with music occurs even since the first year of life, we can really talk about a first stage of development in the artistic direction beginning with preschool ( 3 years old), known under the name of preoperative intelligence stage, when the child develops from a mental point of view, acting particularly with objects. During this period, the affectiveemotional side is predominant, having an unquestionable value for the child, music being regarded as a particularly relevant field. In this sense, we can organize various activities for learning music through age-appropriate songs, accompanied by movement, through actual games, through exercises for developing musical memory, hearing, etc.

\section{MUSIC THEORY-CONCEPTUAL AND PRAGMATIC. FRAMEWORK IN THE DEVELOPMENT OF MUSICAL HEARING}

Music Theory - Solfeggio - Dictation is the basic subject in the development of musical reading and writing skills, in the development of hearing, memory and thinking. , In this context, the issue of the development of skills, abilities, capabilities for receiving and decoding the musical text must not be limited to revealing a primary linear order (...), but it must be oriented, as much as possible, towards a tree development, simultaneous, that would include advanced aspects of musical thinking (dynamics of tonal organization, morphological and syntactic articulations, basic transformational processes etc.)" ${ }^{\prime 59}$. Referring to children following the intensive study of music in specialized high schools, we can say that around the age of 6 , the learning and understanding ability of the child increases, compared to the pre-school period, being doubled by the desire to know better the surrounding reality. The playing and singing activities are continued, adding to them the study of musical notation by means of solfeggio and dictation.

This new stage is more complex due to the substantial effort made by children to appropriate musical notation elements and to use them in solfeggio and dictation. School textbooks do not always provide the necessary support for the thorough assimilation of musical knowledge, this being one of the reasons why the professor should intervene with other auxiliary sources, more efficient from a didactic and artistic point of view. From my own teaching experience with the students from music classes I - XII from the „Octav Bancila " National

\footnotetext{
${ }^{58}$ Pantelimon Golu, Emil Verza, Mielu Zlate - Psihologia copilului/Child Psychology, București, Editura Didactică și Pedagogică, 1995, p.27

${ }^{59}$ Gheorghe Duțică - Solfegiu. Dicteu. Analiză muzicală/Solfeggio.Dictation. Musical Analysis, Iași, Editura Artes, 2004, Argument
} 
High School of Art of Iasi, who performed at numerous national competitions and Olympiads, I can state that it is highly necessary to implement within the learning activities dynamic and effective exercises for each of the chapters concerning intervals, tonality, rhythm and meter.

Looking progressively at the objectives of this subject, in accordance with the requirements of society, there must be a greater concern for the knowledge and development of the skills of a future music performer. His/her success will depend among other things on how he/she has developed musical hearing during school years. Next, we will present all the types of musical hearing, and then we will provide further details for their development in the different stages of the pre-university education.

\section{TYPOLOGIES AND METHODS FOR THE DEVELOPMENT OF MUSICAL HEARING IN THE PRE-UNIVERSITY VOCATIONAL EDUCATION}

\subsection{TYPES OF HEARING}

Musical hearing knows different stages of appropriation, from the intuitive period to the logical thinking one. For the complete development of future musicians, musical hearing needs to be improved so that students would acquire all its typology, together with the elements of style and language of different eras. Also, many well known musical works from the specialized literature will be made familiar. The types of musical hearing that will be presented in the following are: melodic, polyphonic, harmonic (static and processual), dynamic, timbral, internal hearing and sense of rhythm. For the development of each category, the most efficient didactic methods and ways must be found.

\subsection{DEVELOPMENT OF THE MELODIC HEARING}

\section{What does the idiom ,melodic hearing" mean?}

Melodic hearing represents the totality of the mental capacities of perceiving sound in subsequent sonorous relationships. The primary entity from which we start is the musical interval. If in the pre- university education the study of intervals is achieved only through the major-minor functional tonal system, rarely reaching the issue of modes of Romanian popular type, in the academic environment students must appropriate the melody in a close relation to each stylistic periods: Middle Ages - Renaissance; Baroque; Classicism; Romanticism; Folklore; Atonalism; Neo-folklore etc. In the education from Western Europe the material basis consists of the well-known musical literature, focusing on the close connection between Music Theory and other related subjects: Harmony, Counterpoint, Musical Forms. We would add here the need to develop personal musical examples, of a didactic nature, which can consolidate certain problems related to relevant chapters of the subject in question. Since the didactic content and methods vary from one stage to another of student learning, we will continue to offer solutions for the improvement of the melodic hearing for each stage of the vocational education. 


\subsubsection{IMPROVEMENT OF THE MELODIC HEARING IN PRIMARY VOCATIONAL EDUCATION}

For the development of melodic hearing at a young school age, in the vocational education, a series of evolutionary steps must be followed, using exercises with a growing complexity, in accordance with the curriculum requirements.

I. Construction and vocal practice of the intervals in major scales, with their minor relatives (all variations), in both directions, on each scale, in order to develop the sense of tonality; intonation of chains of intervals, different quantitatively or qualitatively, by creating short tonal melodic lines; intonation of the characteristic intervals and of their solution (classes III-IV);

II. Intonation of intervals of thirds, fourths, fifths, octaves by continuous or broken arpeggio figures, ascendant and descendant, which will constitute the preparatory phase of thinking the main and secondary harmonic functions;

III. Recognition of the intervals in the melodic arrangement, after the quantitative and qualitative criteria; the exercises will take into consideration the use of the comparative method, through transformations of an interval-mesh;

IV. Learning by ear (class I) songs with text, specific to young school age, with their melodic analysis. The repertoire will be chosen with great care so as to attract, to contain texts related to childhood, dynamic, possibly transformed in a game;

V. Musical audition of fragments from the universal literature and their analysis in terms of intonation;

VI. Memorizing certain didactic themes or themes from the universal literature;

VII. Melodic solmization of certain examples from classic literature or personal and their analysis;

\section{Intonational dictation:}

- the usage of oral melodic dictation exercises, with didactic character, where the new elements are brought in gradually and are inserted through those previously consolidated;

- melodic dictation or written rhythmic-melodic dictation;

IX. Auto-dictation - writing from memory, on notes, of the melodic lines from songs, studied solfeggios or of certain melodies remembered from musical auditions. The number of measures will increase gradually, from four to eight or even 12 (Class IV). This process develops very efficiently the musical memory and internal hearing.

The deeper the awareness of the perceptions will be, the more voluntary, logical and lasting the musical memory of a child will be.

\subsubsection{IMPROVEMENT OF THE MELODIC HEARING IN SECONDARY VOCATIONAL EDUCATION}

The syllabus for classes V-VIII provides intensive study of all 30 tonalities, to which ,in class VII, the diatonic heptachordic Romanian popular modes are added. Often though, the issued related to the modal system are treated superficially, professors focusing exclusively on the thorough study of the functional major - minor tonal one. Within tonality, great emphasis is placed on the study of intervals, of the arrangements of three sounds, reaching fugitively the problem of the chromatization of the major and minor scales, of the modulation (treated only through the horizontality of the melodic line). The study of rhythm, of the exceptional divisions, of the heterogeneous, alternative measures acquire a greater consistency, these requiring many specific exercises.

Returning to the issue of the development of the melodic hearing, along with what I previously presented related to primary education, one can resort to 
musical literature of the musical Baroque or Classicism. Thus, we may select themes or other fragments for solmization, analysis and dictation:

- passacaglia or preclassical Ciaccona : Corelli, Bach, Handel, Vivaldi;

- Concerto grosso: Vivaldi or Corelli;

- oratories: G. Fr. Handel and J. S. Bach;

- Brahms and sonatas for solo violin and solo cello

- J. S. Bach; focus on the rhythms from the preclassical dances found in suites;

- preclassical concerts;

- arias from preclassical operas;

- arias from the works of W. A. Mozart;

- sonatas, concerts, quartets, symphonies, vocal-symphonic works of Viennese classics: Haydn, Mozart, Beethoven.

These musical materials can be used in all types of activities that target the development of musical hearing:

- practicing the melodic line, without rhythm (intonational solmization);

- analysis of the interval content from a given text;

- omission of a sentence from the content of the fragment, students must build it, respecting the original musical material, based on the binomial antecedent - consistent;

- writing after dictation of themes heard on piano;

- memorizing of famous themes from musical works belonging to Baroque and Classicism;

- auto-dictation of musical fragments from memory;

- deletion, additions, corrections, encirclement, completions, withdrawals of certain phrases or musical periods.

\subsubsection{IMPROVEMENT OF THE MELODIC HEARING IN UPPER SECONDARY VOCATIONAL EDUCATION}

During preadolescence (14 -16 years), mental development knows new and complex dimensions. As stated by an important Romanian psychologist, ", individualization intensifies on the intellectual and relational plans /.../ The interest for abstract and synthesis issues starts to grow, but also for the participation in special roles /.../ affective experience shades and is impregnated with values "60. Adolescence itself (16 -20 years old) has a special feature, the abstract thinking, so necessary to the field that we deal with. „Personal taste has greater poignancy and can be argued and demonstrated. The socialization of aspirations, the vocational aspects, the professionalization, which is gradually framed, are also intense." ${ }^{61}$

Considering all the mental accomplishments of the adolescent, as well as the general objectives of the subject Music Theory for this age, we see as necessary a brief presentation of the syllabus, reflecting more on the forms, means and methods by which melodic hearing fully develops. Along with the understanding of the laws that govern the major minor functional tonal system, during high school more and more knowledge linking the discipline concerned with Harmony are targeted. What was studied so far more practically through solfeggio and dictation, gets now a more scientific consistency, by adding chapters as Natural Resonance of the Sounds (fundamental rules in the Tonal Harmony), Theory of Intervals - solving of dissonances and voice movement,

\footnotetext{
${ }^{60}$ Ursula Şchiopu, Emil Verza - Psihologia vârstelor/Age Psychology, București, Editura Didactică și Pedagogică, 1981, pp.177-178

${ }^{61}$ Idem, p. 178
} 
Functional Chromatization of the Tonality, Tonality - Chords of seventh and fifth; Modulation in close and far tonalities; Musical rhythm - Processes for the classical development of rhythm; Musical keys; Modal System (oligochordic, pentatonic, hexa- and heptachordic); Rhythms of popular origin; Polyrhythmia and polymetria etc.

In order to develop melodic hearing, the study of melodic intervals is intensified, using the Autodidactic Study Method (Intervals, chords, rhythm) of Professor Iulia Bucescu, in which the exercises of intervallic construction cover efficiently and in a relatively short period of time the entire framework of tonalities. In this way, students will no longer be inhibited by the presence of double and single musical alterations or by solfeggios with a more consistent armor (five to seven alterations). We recommend using examples from the well known musical literature, many of them being selected and organized on different issues in different typologies of exercises and questionnaires with auditions, appeared in volumes of dynamic learning of the subject of Music Theory.

\subsection{DEVELOPMENT OF THE POLYPHONIC HEARING}

Polyphonic hearing is the superior quality to distinguish each voice from a polyvocal texture having distinct rhythmic-melodic personality. The need to develop this type of hearing is reinforced by the multitude of aspects that children should appropriate: synchronization, distributive attention to other voices, compliance with the dynamic plans and vocal and instrumental outlining of the counterpoint writing. Let us not forget that students study from a young age an instrument, especially piano, often finding polyphonic writing in musical scores. In the same direction, the polyphonic quality of the hearing can be developed through:

I. Audition of polyphonic works from the Renaissance and Baroque musical period, as well as the modal music of the twentieth century

II. Recognition and analysis of certain melodic lines from the polyphonic texture;

III. Solmization of several musical examples, collectively, having an increasingly higher degree of complexity;

IV. Polyphonic dictation for two, three or four voices, with the analysis of the non-imitative or imitative writing;

V. Interpretation of certain polyphonic examples, simultaneously, by the same child, at the piano and with the voice; I observed this method when it was applied to young classes at the "Ciprian Porumbescu" Musical High School in Chisinau, with very good results in the development of polyphonic and harmonic hearing.

\subsubsection{DEVELOPMENT OF THE POLYPHONIC HEARING IN PRIMARY EDUCATION}

In vocational pre-university education, unfortunately, the development of polyphonic hearing is not among the main objectives of the subject Music Theory. Only in class V, within the subject Choir, students come into contact with the true polyphonic art. Nonspecialist people ignore this subject, trying to relieve many instrumentalists of the "chore" of the Choir, not wanting to understand the huge importance of this discipline. Within the subject of Music Theory, polyphonic singing is rarely practiced, under the form of strict canon in the few existing solfeggios from the textbooks, examples that are often lacking 
musicality or themes that are not suitable for writing in canon at the desired interval. The preference of professors only for the study of monody is not justified, our explanation being related to the convenience in the selection of attractive excerpts from the choir literature for children, represented in the works of composers such as: Max Eisikovici, Dan Buciu, Gheorghe Dutica, Sabin Pautza, Felicia Donceanu or Dan Voiculescu. Personally, I was concerned with the introduction of primary elements of heterogeneous or imitative polyphony even since class I, developing a manual that contains a special chapter on polyphony: singing with accompaniment, alternative and in canon singing, filled throughout with other adjacent examples from choirs, as accessible as possible.

Observing the attraction of the children towards pluri-vocal singing, I have formed a choir of primary school pupils, Alpha Lirae, and I teached them, among other things, to use during vocal singing the percussion instruments from the diverse range of the German composer Carl Orff. Over the years, I have watched their musical progress, the children developing may skills such as: vocal technique of chant, hearing, memory, sense of rhythm, attention, homogenisation within the group, reading at first sight of a text, the assimilation of a vast luggage of Romanian and universal repertoire etc.

\subsubsection{DEVELOPMENT OF THE POLYPHONIC HEARING IN SECONDARY EDUCATION}

During secondary school the effort for the development of polyphonic hearing through the study of polyphonic vocal works from Renaissance, composed for choirs of equal voices (two, three and four voices) is continued. A multitude of examples of Baroque vocal and instrumental literature, culminating in the works of the composers G. Fr. Haendel and J. S. Bach are also included. To these, the particularly inspired modern arrangements may be added, being based on themes belonging to Bach or Mozart, and that emerged on the western musical market, written especially for choirs of equal voices, very attractive for students. This period is beneficial also because students from classes V-VIII study the subject Choir.

\subsubsection{DEVELOPMENT OF THE POLYPHONIC HEARING IN UPPER SECONDARY EDUCATION}

Given that polyphonic hearing would already be improved after eight years of study of vocal and instrumental polyphony, during high school years the repertoire remains to be expanded by introducing in solmization of more complex fragments from the Romanian and universal literature, analyzed and interpreted, to the extent of their full understanding. It is recommended that two to three examples of its kind to exist every week in the Music Theory classes, creating a special delight to young performers, making the discipline more attractive, dynamic and practical.

\subsection{DEVELOPMENT OF THE HARMONIC HEARING}

Based on the concept that any tonal melody is based on a predetermined harmonic support, it should be emphasized that harmonic hearing development is a particularly important objective in understanding and interpreting tonal and modal scores. If performers of keyboard instruments have a greater chance in 
developing harmonic hearing since early stages, we may not state the same about those who study monodic instruments (stringed or wind). For these a few quick and successful solutions must be considered

I. Individual vocal practice of certain melodic intervals or of short arpeggios at high speed, up to the sensation of simultaneity of sounds; vocal intonation on two or more voices of intervals and chords;

III. Musical audition of works based on homophony, following the musical text from the musical score - manner of developing internal harmonic hearing;

IV. Group solmization of homophone texts and their analysis from an harmonic point of view;

V. Practicing on the piano of musical works performed homophonously.

\subsubsection{DEVELOPMENT OF THE HARMONIC HEARING IN PRIMARY EDUCATION}

Most often the development of harmonic hearing is neglected, students and their teachers putting a greater emphasis on its melodic quality. Although it is known that tonality can only be understood in terms of harmonic thinking, of attractiveness relations attractive towards a base centre called tonic, the study of thirds starts in class IV, insisting only on the main scales. This stage needs a prior period, when one must insist on the harmonic solfeggio on two voices and three voices, without entering into detailed explanations on the structure and tonal relationships. Ion Gagim captures very well the moments of harmony perception in children,, a) noticing the modal functions of chords, b) noticing the character of the musical chord verticality in its performance, that is of the artistic expression /.../ we differentiate two types of harmonic hearing : 1) vertical harmonic hearing (static); 2) horizontal harmonic hearing (procedural): movement on the line of chords and harmonic successions in their semantic, theatral dynamics. "62. We conclude by saying that it is not enough to practice each chord type separately, if they are not then studied chained in time. Only in this way they can be compared in terms of importance, expression, as tension and solution.

\subsubsection{DEVELOPMENT OF HARMONIC HEARING IN SECONDARY EDUCATION}

However, once the small school age has passed, when all students begin studying the piano and some of them attend classes of Choir, the development of the harmonic hearing intensifies. Within the classes of Music Theory it is necessary to priorly perpare a homophon solfegistic repertoire and simplified harmonic dictation, as much as possible, in terms of rhythm.

\subsubsection{DEVELOPMENT OF HARMONIC HEARING IN UPPER SECONDARY EDUCATION}

In high school, students begin to study the subject Harmony, and within Music Theory the professor insists increasingly on the development of an harmonic thinking through the frequent analysis of the texts from the universal musical literature. Thus, the seventh and fifth chords of dominant are studied, these being represented in various harmonic contexts. Since ninth grade certain issues concerning tonal cadences will be clarified, insisting more on the during university years. Solving dissonances, voices movement, authentic relationships

\footnotetext{
${ }^{62}$ Ion Gagim - op.cit., p. 150
} 
between scales, all this knowledge should not be absent from the learning process during high school. Harmonic solfeggios with didactic role or from the known classical repertoire are recommended (Constantin Ripa - Solfegii la două voci/Solfeggio on two voices), fragments from choirs, vocal-symphonic repertoire, that would contain problems related to the solving of dissonances, diatonic, chromatic and enharmonic modulations. ${ }^{63}$.

Modern technology should not be missing from the classes of Music Theory. In the French didactic literature there are whole cycles of volumes with attached CDs, containing excerpts from classical music literature or modern one, where there are requirements for those who listen to the texts. For instance:

- Fill in the cadences that you see in the musical score

- Find five mistakes intentionally added in the following harmonic structures;

- Fill in the fourth voice from the fragment excerpted from the Ninth Symphony of Ludwig van Beethoven , Part III, etc.

We will also encounter exercises covering almost all chapters from the Music Theory, except the modal system. It seems that it is the duty of the Eastern schools to follow the example of the German, French or English schools of theory and to give a valuable reply through the elaborated didactic work on issues concerning traditional modalism and specific rhythms of musical cultures of oral tradition.

\subsection{DEVELOPMENT OF SENSE OF RHYTHM}

Rhythm directs everything alive, moving, governing the principle of evolution and development, ordering the sound events. As stated by Victor Giuleanu, , rhythm is the phenomenon of the evolution in time and organized paging of all acts, processes and events from nature, society, physical and mental human life "64. Even since Ancient Greece, philosophers as Aristotle or Heraclitus believed that rhythm is synonymous to the phenomenon of movement. Rhythm is configured based on the relationship of the elements of the triad duration - rhythmic accent - formula, knowing variations both at microtemporal level, as well as in the stage of macroform. ${ }^{65}$. Furthermore, the rhythm interferes with the tempo and musical metric, between these three phenomena existing a permanent interdependence.

\subsubsection{DEVELOPING THE SENSE OF RHYTHM IN PRIMARY EDUCATION}

The study of musical rhythm itself must represent a permanent concern, closely related to other parameters, the examples from the universal literature being the main resources that lead to making the teaching approach more effective in vocational high schools. For young school children, the elementary notions about rhythm are studied according to their ability of understanding, in

\footnotetext{
${ }^{63}$ Also, a significant source of learning materials is provided by the Internet where you can find both musical scores as well as famous recordings and sometimes, on YouTube, audio moments with the presentation of the musical score may be found, which can be stopped at any time etc.

${ }^{64}$ Victor Giuleanu - Tratat de Teoria muzicii/ Music Theory Treaties, București, Editura Muzicală, 1986, p.563.

${ }^{65}$ See: Gheorghe Duțică, Luminița Duțică - Conceptul ritmic și tehnica variațională. O viziune asupra Barocului și Clasicismului muzical/The Rhythmic Concept and Variational Technique. A Vision of the Musical Baroque and Classicism, Iași, Editura Artes, 2004. This Treaty of Music Theoryal Rhythm brings to attention an original systematization of the variation based on the analysis and typologisation of the rhythmic phenomenon from the two mentioned stylistic periods, both at morphological, as well as syntactic level.
} 
such a way that the basic times remain the quarter note and the eight note, as they are found in all songs specific to childhood. The call for creation for children and study of music through rhythmic or rhythmical and melodic games must represent the main directions of orientation towards acquiring the habits and skills of the children. The University Professor Iulia Bucescu offers solutions for a greater efficiency, safety and speed in the study of rhythmic parameter, which they deserve to be assimilated by us and to apply them in the musical practice ${ }^{66}$.

\subsubsection{DEVELOPING THE SENSE OF RHYTHM IN SECONDARY EDUCATION}

The exercises for developing the rhythmic skills continue in the secondary school by bringing gradually the complexity of the exceptional rhythmic formulas, of those asymmetrical metro-rhythmic, in an intense relationship with the binary, ternary and heterogeneous metrics. It is recommended the intensive study of each type of rhythm and its exceptional formulas by rhythmic, polyrhythmic exercises, in groups and individually, of solmisation with rhythmical accompaniment, of rhythmic dictation, etc. The routine stops the spirit and, therefore, solutions which are as attractive and as dynamic as possible must be sought for developing the sense of rhythm.

\subsubsection{DEVELOPING THE SENSE OF RHYTHM IN THE UPPER SECONDARY SCHOOL}

In high school books, the rhythm encounters a more significant share, through the various exercises to acquire the three types of rhythm, of solfeggio with rhythm accompaniment, as well as through study of polyrhythm or of polymetrics. The main classic processes for rhythm development are briefly presented (10 grade), with only a few examples of the universal musical creation. We recommend them numerous other illustrative example, as well as systematisation of all configurative rhythmic, melodic- and rhythmic or rhythmic and polyphonic operations, viewed both horizontally and in the vertical syntaxes ${ }^{67}$.

\subsection{DEVELOPING THE DYNAMIC AND TIMBRAL HEARING}

The areas insufficiently explored and exploited within the subject Music Theory remain those of the nuances and timbrality (instrumental or vocal). The knowledge of the modalities of emission, articulation, phrasing and orchestration are not concerns of didactics in the vocational high schools in Romania. But, in the Western education, the concerns are numerous: French teaching literature abounds of testing cycles based on musical auditions and learning some features related to dynamics and timbres. We recommend the musical audition and also analysing these parameters, the exercises for recognising some instruments by their separation from different polyphonic or harmonic chords, found in chamber or symphonic genres of the most varied stylistic periods.

\footnotetext{
${ }^{66}$ See: Iulia Bucescu - Music Theory: Autodidactic study methods: intervals, chords, rhythm, Ploieşti, Editura LiberArt, 1994

${ }^{67}$ See: Gheorghe Duţică, Luminiţa Duţică, op. cit.
} 


\subsection{DEVELOPING THE INTERNAL HEARING}

The internal hearing represent the superior quality, by which the music can be heard and reproduced inside the human body, without using an external audio source. Its aspects can be melodic, harmonic, polyphonic etc. The internal hearing is formed by numerous auditions, having the score in front, accompanied by thorough and varied analyses of content, by solmisation, dictation and autodictation of some musical fragments from memory. In this regard, we should remember the great composer L. van Beethoven who, even if he became deaf after a certain age, he continued to compose musical works with an astonishing complexity. The explanation is that he had a highly developed internal hearing, and the memory stored an important base of information, which helped him in the composition. The exercises for developing the internal hearing start in the small grades by studying several musical works for children, memorising them, alternative chanting in the form of game - loud and in mind of some fragments in songs and teaching solfeggios, by musical dictation and autodictation, auditions (with the score in front) and analysis of language elements to logically memorise a work. The internal hearing acquired relevance along with the increase of knowledge in the musical field.

\section{Conclusions}

The auditory musical system is one of the foundations of the development of a future artist. The study of music is performed by involving all mental processes: perception, representation, attention, affection, memory, language, thinking, motivation, creativity, etc. One of the key elements that ensure success in this field is the hearing, quality through which the musical sonorous world is perceived and analyzed. Through the forms of musical hearing, opuses are heard, recognized, reproduced, experienced and analyzed.

As we demonstrated during our study it is necessary to know and gradually apply different didactic strategies in the development of musical hearing (melodic, polyphonic, harmonic, timbral or internal), that would ensure a complete success in shaping the future musician: singer, songwriter, conductor and pedagogue.

\section{References}

1. Bucescu, I. (1994). Teoria muzicii. Metodă de studiu autodidact: intervale, acorduri, ritm. Ploiești: LiberArt

2. Duţică, Gh. (2004). Solfegiu, Dicteu, Analiză muzicală. Iași: Artes

3. Duţică, Gh., Duţică, L. (2004). Conceptul ritmic şi tehnica variaţională. O viziune asupra Barocului şi Clasicismului musical. Iași: Artes

4. Duțică, L. (2015). Iulia Bucescu - Based of Musical Teaching - Novelty, Originality, Creativity. Review of Artistic Education, 9-10

5. Gagim, I. (2003). Dimensiunea psihologică a muzicii. Iași: Timpul

6. Golu, P., Verza, E., Zlate M. (1995). Psihologia copilului. București: Didactică și Pedagogică

7. Giuleanu, V. (1986). Tratat de Teoria muzicii. București: Muzicală

8. Șchiopu, U., Verza, E. (1981). Psihologia vârstelor. București: Didactică și Pedagogică 